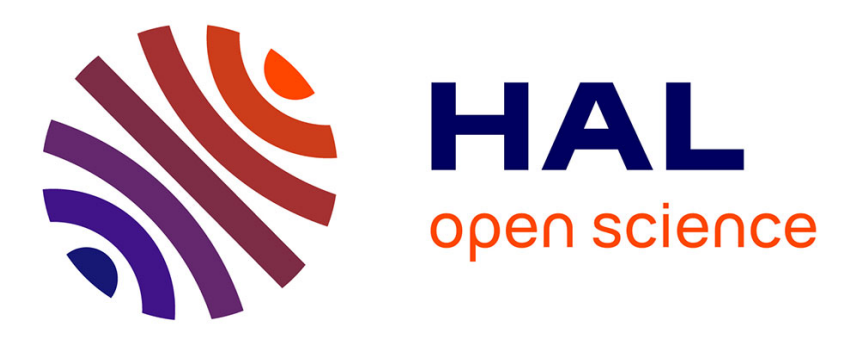

\title{
Evaluation of the presence of the bap gene in Staphylococcus aureus isolates recovered from human and animals species.
}

\author{
Eric Vautor, G. Abadie, A. Pont, Régis Thiery
}

\section{- To cite this version:}

Eric Vautor, G. Abadie, A. Pont, Régis Thiery. Evaluation of the presence of the bap gene in Staphylococcus aureus isolates recovered from human and animals species.. Veterinary Microbiology, 2008, 127 (3-4), pp.407-11. 10.1016/j.vetmic.2007.08.018 . hal-00409215

\section{HAL Id: hal-00409215 https://hal-anses.archives-ouvertes.fr/hal-00409215}

Submitted on 16 Nov 2009

HAL is a multi-disciplinary open access archive for the deposit and dissemination of scientific research documents, whether they are published or not. The documents may come from teaching and research institutions in France or abroad, or from public or private research centers.
L'archive ouverte pluridisciplinaire HAL, est destinée au dépôt et à la diffusion de documents scientifiques de niveau recherche, publiés ou non, émanant des établissements d'enseignement et de recherche français ou étrangers, des laboratoires publics ou privés. 
4 Evaluation of the presence of the bap gene in Staphylococcus 5 aureus isolates recovered from human and animals species 6

7

8 E. VAUTOR*, G ABADIE, A. PONT, R THIERY

9

10

11 AFSSA (French Food Safety Agency), Small Ruminants Pathology Unit, BP111, 06902

12 Sophia-Antipolis Cedex, France

13

14

15

16

* Corresponding author. Tel (33) 49294 3711; Fax (33) 492943701.

17 E-mail address: e.vautor@sophia.afssa.fr

18

19

20

21

22

23

24

25

26

27 
Abstract:

The implication of biofilm in chronic bacterial infection in many species has triggered

30 an increasing interest in the characterization of genes involved in biofilm formation. The bap

31 gene is a newly identified gene that encodes the biofilm-associated protein, BAP, which is

32 involved in biofilm formation in Staphylococcus aureus. So far the bap gene has only been

33 found in a small proportion of $S$. aureus strains from bovine mastitis in Spain. In order to

34 study the presence of the bap gene in S. aureus isolates obtained from other species and 35 various locations, a collection of 262 isolates was tested by PCR, using published primers 36 and dot-blot. The results indicated that none isolates carried the bap gene suggesting that

37 the prevalence of this gene among S. aureus isolates should be very low.

38 Keywords: Staphylococcus aureus; Bap gene; Biofilm; Epidemiology

39

40

\section{Introduction}

54

In Staphylococcus aureus (S. aureus) the implication of biofilm in chronic infections in

56 all animal species have triggered an increasing interest in the characterization of genes 
57 involved in this biofilm formation. For example, the biofilm formation is important for virulence 58 in mastitis (Baselga et al., 1993). A new gene $(6,831$ nucleotides) involved in biofilm 59 formation (bap coding for a biofilm-associated protein, Bap) was identified in a small 60 proportion of S. aureus from bovine mastitis (Cucarella et al., 2001). The bap protein is a 61 member of proteins playing a role in biofilm formation in many bacteria. They share common 62 structural features as they have a high molecular weight and contain a core domain of 63 tandem repeats. These proteins confer upon bacteria the capacity to form a biofilm and play 64 a relevant role in bacterial infectious process. Some of these proteins are contained occasionally in mobile elements (Lasa and Penades, 2006). In S. aureus, the bap gene is

66 carried by a putative composite transposon inserted in SaPIbov2, a mobile staphylococcal 67 pathogenicity island. Bap orthologue genes have been found in other staphylococcal species 68 including Staphylococcus epidermidis, Staphylococcus chromogenes, Staphylococcus 69 xylosus, Staphylococcus simulans and Staphylococcus hyicus. However, sequence analyses 70 of the flanking regions revealed that these orthologue bap genes of these staphylococcal 71 species were not contained in the SaPlbov2 pathogenicity island (Tormo et al., 2005).

The aim of the present study was to investigate the presence of bap gene in various S. aureus isolates recovered from human and different animal species. To do this a published PCR method was used (Cucarella et al., 2001) and results were confirmed by dot blot analysis.

\section{Materials and methods}

2.1. S. aureus isolates used in the study

80

Two hundred and sixty two S. aureus isolates associated with different diseases were

82 recovered from various locations in France and different animal species (cows, sheep, goats, 83 pigs, rabbits, poultry, horses, human) (table 1). The cow's isolates were a gift from Dr J.L 84 Martel (AFSSA Lyon). Some sheep isolates were from ML De Buyser (AFSSA Maisons85 Alfort). The goat's isolates were partly from Dr P. Mercier (AFSSA Niort). The pig, poultry and 
rabbits isolates were from M.H. Bäyon-Auboyer (Departemental Laboratory Côtes d'Armor). The horse's isolates were a gift from Dr C. Collobert (AFSSA Dozulé). The human isolates were mainly from $\mathrm{Dr} \mathrm{H}$. Carsenti-Dellamonica (Hospital of Archet, Nice, France). All the remaining isolates were from AFSSA Sophia-Antipolis.

2.2. Detection of the bap gene by PCR

DNA extraction was performed using the DNeasy ${ }^{\circledR}$ Tissue Kit (Qiagen, Courtaboeuf,

France) according the manufacturer's instructions with slight modifications. Lysostaphin

(Sigma, St Quentin, France) were added $(1 \mathrm{mg} / \mathrm{ml})$ for enzymatic lysis at $37^{\circ} \mathrm{C}$ for $2 \mathrm{~h}$. PCR wer

performed

twice,

using

a primer

pair

98 CCCTATATCGAAGGTGTAGAATTGCAC 3' and sasp-7c 5' GCTGTTGAAGTTAATACTGTACCTGC 3') as described by Cucarella (Cucarella et al., 2004) to detect the bap gene. Amplification was carried out on a Mastercycler" ${ }^{\mathrm{TM}}$ (Eppendorf,

101 Hamburg, Germany) with Platinium ${ }^{\circledR}$ Taq DNA Polymerase (Invitrogen, Cergy Pontoise,

102 France) under the following conditions: an initial 2 minutes denaturation step at $94^{\circ} \mathrm{C}$; 103 followed by 40 cycles each of 30 seconds at $94^{\circ} \mathrm{C}, 30$ seconds at $55^{\circ} \mathrm{C}$, and 75 seconds at $10472^{\circ} \mathrm{C}$; and a final step at $72^{\circ} \mathrm{C}$ for 5 minutes. A 971-bp PCR fragment was expected. The primer pair (staur4 : 5' ACGGAGTTACAAAGGACGAC 3' and staur6 : 5' AGCTCAGCCTTAACGAGTAC 3') was used to target the 23S rDNA as described by Straub

107 (Straub et al., 1999) to confirm the quality of each DNA extract and the absence of PCR 108 inhibitor. The following conditions were used: an initial 5 minutes step at $94^{\circ} \mathrm{C}$; followed by 30 109 cycles each consisting of 30 seconds at $94^{\circ} \mathrm{C}, 30$ seconds at $58^{\circ} \mathrm{C}$, and 75 seconds at $72^{\circ} \mathrm{C}$; 110 and a final step at $72^{\circ} \mathrm{C}$ for 5 minutes. A 1250-bp PCR fragment was expected.

A bap positive control strain V329 (Genbank accession no. AY220730, kindly 112 provided by $\operatorname{Dr}$ J.R. Penadés, Spain) was used with each PCR run. Amplification products 113 were electrophoresed in a 1\% agarose gel containing ethidium bromide and visualized by 114 transilluminantion under UV light. 
2.3. Dot blotting and hybridisation for the bap gene

For the dot blotting, 141 isolates were randomly chosen among the two hundred and 119 sixty two isolates.

120 The dot blotting technique was described by Planchon et al. (Planchon et al., 2006).

121 Briefly, $50 \mathrm{ng}$ of denatured DNA were spotted onto $\mathrm{N}+$ nylon membrane and treated 122 according to the manufacturer's instructions (Amersham Biosciences, Buckinghamshire, 123 England). The PCR product amplified with the primers sasp-6m and sasp-7c (Cucarella et

124 al., 2004), specific for the bap gene (971 bp long) from the V329 S. aureus strain, was used

125 as the probe. This PCR product was purified with a QIAquick ${ }^{\circledR}$ PCR purification kit (Qiagen,

126 Courtaboeuf, France), labelled with the DIG-High Prime ${ }^{\circledR}$ system (Roche, Neuilly sur Seine, 127 France). The hybridisations were done in DIG Easy $\mathrm{Hyb}^{\circledR}$ solution and the hybridised probe 128 was detected by the Dig colour detection ${ }^{\circledR}$ kit (Roche, Neuilly sur Seine, France) following the 129 manufacturer's instructions. S. aureus V329 (Genbank accession no. AY220730) was used 130 as positive control and the strain Mu50 (Genbank accession no. BA000017) as negative 131 control.

\section{Results}

DNA extracted from 262 S. aureus isolates was tested for the presence the bap gene by $\mathrm{PCR}$, using the primer pair sasp-6m and sasp-7c, as indicated in the materials and

137 methods section. Although the positive control strain (V329) showed a band at $971 \mathrm{bp}$, as 138 expected, none of the tested isolates showed positive results. All isolates were also tested 139 for the presence of the S. aureus 23S DNA by using PCR to check for DNA quality, presence 140 of inhibitors of the PCR reactions and specificity. All isolates were found positive, thus 141 eliminating false negative results. An example of some PCR results is shown in figure 1. Since it cannot be excluded that mutations or deletions could have occurred in the 143 primer pair region of the bap gene, 141 isolates were randomly selected and tested by dot 
144 blotting. As illustrated in figure 2, all isolates were also found negative by using this 145 technique, except the bap positive control strain V329. Therefore it is likely that the bap gene 146 is lacking in all isolates of $S$. aureus tested in this study.

\section{Discussion}

The gene for the biofilm associated protein (bap gene) was not detected in the twenty hundred and sixty two S. aureus isolates of this study. These results are in agreement with previous surveys on S. aureus of human, bovine, rabbit and pig origins (Arciola et al., 2001;

154 Vasudevan et al., 2003; Vancraeynest et al., 2004; Nitzsche et al., 2007) where the bap gene 155 was not found in the S. aureus isolates recovered in these animal species of these studies. 156 Our study is the first one with a wide range of $S$. aureus recovered from different animal species to show that the bap gene had not spread yet among S. aureus.

So far, the bap gene has only been found in $S$. aureus obtained from bovine subclinical mastitis in Spain (Cucarella et al., 2001). This gene is also present in other

160 Staphylococcus species, including S. epidermidis, S. chromogenes, S. xylosus, S. simulans 161 and S. hyicus (Tormo et al., 2005; Planchon et al., 2006). But, the bap gene is not widely 162 distributed in S. aureus isolates despite its presence in the pathogenicity island SaPlbov2, a 163 mobile genetic element. Analysis of the bap flanking sequences revealed that bap is carried 164 by a transposon-like element. The transposon is inserted in the pathogenic island SaPlbov2 165 which is mobile without the presence of a helper phage (Penadés, 2006). The ability to 166 produce biofilms, associated with the presence of the bap gene has been shown to give 167 growth and persistence advantage to isolates from bovine chronic mastitis (Cucarella et al., 168 2004). But, S. aureus is fully capable of forming biofilm in the absence of bap gene as shown 169 for some isolates (Vautor et al., 2006). These isolates were associated with the well-known 170 operon icaADBC (manuscript in preparation). As producing biofilm is an advantage for 171 virulence, it was the purpose of this study to look for the bap gene in S. aureus pathogenic 172 isolates. We propose two hypothesis, to be confirmed, explaining why the bap gene had not 
173 spread amongst others S. aureus strains: i) the bap gene must have been acquired recently

174 by $\mathrm{S}$. aureus in SaPlbov2 and consequently the gene has not been horizontally transferred

175 yet ii) horizontal gene transfer is not easy between different $S$. aureus lineages due to their

176 host specificities. The S. aureus lineages are supposed to be different between strains

177 recovered from different animal species. The Sau1 type restriction-modification system found

178 in S. aureus is one of specifics mechanism that controls the ability of mobile genetic element

179 to spread between strains (Waldron and Lindsay, 2006).

180 In conclusion, this study indicated that none isolates carried the bap gene suggesting

181 that the prevalence of this gene among S. aureus isolates should be very low. Finally, no

182 evidence of horizontal transfer of the bap gene between S. aureus recovered from different

183 animal species was found.

184

185

186

187

Acknowledgements

188

We thank Dr José Penades (Cardenal Herrera-CEU University and Instituto Valenciano de Investigationes Agrarias, 46113 Moncada, Valencia, Spain) for helpful discussion. 
Arciola, C.R., Baldassarri, L., Montanaro, L., 2001. Presence of icaA and icaD genes and slime production in a collection of staphylococcal strains from catheter-associated infections. J. Clin. Microbiol. 39, 2151-2156.

208 Baselga, R., Albizu, I., De La Cruz, M., Del Cacho, E., Barberan, M., Amorena, B., 1993. Phase variation of slime production in Staphylococcus aureus: implications in colonization

211 Cucarella, C., Solano, C., Valle, J., Amorena, B., Lasa, I., Penades, J.R., 2001. Bap, a 212 Staphylococcus aureus surface protein involved in biofilm formation. J. Bacteriol. 183, $213 \quad 2888-2896$

214 Cucarella, C., Tormo, M.A., Ubeda, C., Trotonda, M.P., Monzon, M., Peris, C., Amorena, B., 215 Lasa, I., Penades, J.R., 2004. Role of biofilm-associated protein bap in the pathogenesis 216 of bovine Staphylococcus aureus. Infect. Immun. 72, 2177-2185.

217 Lasa, I., Penades, J.R., 2006. Bap: a family of surface proteins involved in biofilm formation. Res. Microbiol. 157, 99-107.

219 Nitzsche, S., Zweifel, C., Stephan, R., 2007. Phenotypic and genotypic traits of Staphylococcus aureus strains isolated from pig carcasses. Vet. Microbiol. 120, 292-299.

Penadés, J. R., 2006. Protein-mediated biofilm formation in bacteria: the Bap model. International Symposium on Staphylococci and Staphylococcal infections, Maastricht, The Netherlands.[12th, 3-6 September 2006], 63-66.

224 Planchon, S., Gaillard-Martinie, B., Dordet-Frisoni, E., Bellon-Fontaine, M.N., Leroy, S., Labadie, J., Hebraud, M., Talon, R., 2006. Formation of biofilm by Staphylococcus xylosus. Int. J. Food Microbiol. 109, 88-96.

227 Straub, J.A., Hertel, C., Hammes, W.P., 1999. A 23 S rDNA-targeted polymerase chain 228 reaction-based system for detection of Staphylococcus aureus in meat starter cultures 229 and dairy products. J. Food Prot. 62,1150-1156.

230 Tormo, M.A., Knecht, E., Gotz, F., Lasa, I., Penades, J.R., 2005. Bap-dependent biofilm 231 formation by pathogenic species of Staphylococcus: evidence of horizontal gene transfer? $232 \quad$ Microbiology 151, 2465-2475. 
233 Vancraeynest, D., Hermans, K., Haesebrouck, F., 2004. Genotypic and phenotypic screening

234 of high and low virulence Staphylococcus aureus isolates from rabbits for biofilm formation 235 and MSCRAMMs. Vet. Microbiol. 103, 241-247.

236 Vasudevan, P., Nair, M.K., Annamalai, T., Venkitanarayanan, K.S., 2003. Phenotypic and 237 genotypic characterization of bovine mastitis isolates of Staphylococcus aureus for biofilm 238 formation. Vet. Microbiol. 92, 179-185.

239 Vautor, E., Carsenti-Dellamonica, H., Sabah, M., Mancini, G., Pépin, M., Dellamonica, P., 240 2006. Characterization of Staphylococcus aureus isolates recovered from dairy sheep 241 farms (agr group, adherence, slime, resistance to antibiotics). Small Rumin. Res. In press. 242 Waldron, D.E., Lindsay, J.A., 2006. Sau1: a novel lineage-specific type I restriction243 modification system that blocks horizontal gene transfer into Staphylococcus aureus and 244 between S. aureus isolates of different lineages. J. Bacteriol. 188, 5578-5585. 